\title{
Leverage and the Jordanian Firms' Value: Empirical Evidence
}

\author{
Imad Zeyad Ramadan ${ }^{1}$ \\ ${ }^{1}$ Department of Finance, Applied Science University, Amman, Jordan \\ Correspondence: Imad Zeyad Ramadan, Associate Prof., Department of Finance, Applied Science University, \\ P.O. Box 166, Amman, Jordan. E-mail: i_ramadan@asu.edu.jo
}

Received: December 25, 2014

Accepted: January 6, 2015

Online Published: March 25, 2015

doi:10.5539/ijef.v7n4p75

URL: http://dx.doi.org/10.5539/ijef.v7n4p75

\begin{abstract}
This study aimed to investigate the assumed impact of the leverage on the firms' value utilizing unbalanced pooled Ordinary Least Square (OLS) cross-sectional time series panel data regression approach to all listed companies in Amman Stock Exchange (ASE) during the period 2000-2013 after excluding the financial sector and services sector, due to their own characteristics. F-test was used to test the hypothesis that the changes in the firms' leverage level significantly explain the changes in the firms' value. The results shows that the firms' leverage level affect the firms' value for the Jordanian listed companies included in the sample test. This result is consistent with the result of Rajan and Zingales (1995) who find inverse association between debt and performance.
\end{abstract}

Keywords: leverage, firm value, Jordan

\section{Introduction}

The association between Leverage and the value of the firm has been the subject of significant discuss theoretically and empirically. Discuss have concentrate on whether the optimum capital structure exist and if there is an impact of the debt's level and the value of the firm. Pandey (2004) indicate that, the capital structure decision depend on its effects on the firm's value, thus, the capital structure of the firm would be the mixture, between equity and debt, that maximize the firm's value. An optimal capital structure is obtained when the firm's value is maximized along with minimum cost of capital (Firer et al., 2004; Erhardt \& Brigham, 2003).

Empirical studies have found evidence that support the direct association between firm's performance and their optimal or leverage level: Ward and Price (2006) concluded a direct and significant relationship between leverage and profitability. Sharma (2006) found that leverage and performance are positively correlated. Lasher (2003) concluded a positively relationship between debt ratio and earnings per share (EPS) and return on equity (ROE) as profitability proxies. Conversely, Ebaid (2009), concluded that capital structure has no significant effect on the firm's performance. Tian and Zeitun (2007) find out that Leverage have a negative significant effect on the firm's performance using accounting and market measures for performance.

Modigliani and Miller (1958) known as MM I, considered the starting point for most studies on capital structure. MM I derived the Leverage Irrelevance theory, stating that capital structure has no effect on the firm's value in an ideal environment that has no tax, inflation or transaction costs. This MM I received substantial criticism from researchers who questions the realistic of the MMI theory assumptions.

This substantial criticism stimulates Modigliani and Miller (1963) to issue a correction to MMI theory known as MMII. In MMII Modigliani and Miller still quarrel that the transform in the leverage level does not affect the firm's value, but when taxes and other transaction costs are considered two factors need to be recognized: First, the firm's weighted average cost of capital goes downward as leverage level goes upward. Second, the increase in the leverage level will affect the firm's cost of equity positively due to the fact that investors bear higher business risk cause by the increase in the leverage level as it increase the possibility of bankruptcy.

Although Leverage and its affect on the firm's value had been study for long, it stills a subject of controversy and disagreement among researchers. Accordingly, there is a set of questions still need to be answered, such as: What is the optimal mixture between equity and debt firm has to adopt? If it does, to what extend can the debt ratio maximize the value of the firm? If there is an optimal capital structure, dose it vary among industries?

Based on the above the objective of this paper aims is to investigate the assumed impact of the leverage on the 
firms' value in developing market economies namely Jordan.

The importance of this study stems from the fact that most of the studies on this topic was done in developed markets and only little evidence are available from developing markets. Knowing that evidence from developed market cannot be generalize for developing market without research, the main importance of the study comes from trying to find specific evidence of the influence of leverage on the firms' value in developing markets mainly Jordan.

Based on the above, the hypothesis that the study seeks to test can be formulated as follows:

$H_{0}$ : Firms' leverage level has no significant impact on its value.

To achieve the aim of the study and test its hypothesis, unbalanced pooled Ordinary Least Square (OLS) cross-sectional time series panel data regression approach was applied to selected firms listed in Amman Stock Exchange (ASE) for the time horizon 2000-2013.

\section{Theoretical Formwork}

\subsection{Pecking Order Theory (POT)}

Pecking order theory was first featured by Donaldson in 1961 and then modified by Stewart C. Myers and Nicolas Majluf in 1984. Pecking order theory states that funding priorities in corporate finance start from the internal financing to the equity, according to the cost of funding, and raising equity is the last resort in financial decision.

POT is consistent with the idea of asymmetric information, which states that managers have more information about the overall performance of their firms'. This additional information to the managers affects their choice of source of funding between internal and external financing, POT favors' the funding through debt over equity as it signals the board's confidence that the investment is profitable and that the current stock price is undervalued. Funding through equity would signal management distrust and a feeling of overvalued of the stock price. Thus, an issue of stocks would lead to a drop in share price.

Experimental studies in testing the pecking order theory were unable to provide evidence that the theory is considered the most important in explaining the firm's capital structure. Fama and French (2002) and Myers and Shyam-Sunder (1999) concluded the Pecking Order theory was better able to explain some of the data features than trade-off theory. Frank and Goyal (2003) concluded that POT fails where it should hold.

\subsection{Trade off Theory (TOT)}

The classical version of the Trade off theory goes back mainly to the Kraus and Litzenberger (1973) who considered a equilibrium between the weight costs of bankruptcy and the tax saving advantage of debt. This theory is often set up as an alternative theory to the POT.

The TOT aimed to explain the fact that firms usually use a structure of debt and equity to finance their needs of funds, and states that there is an advantage of debt financing, the tax shield, and there is a cost of financing with debt, the financial distress, bankruptcy and non-bankruptcy. The benefits of the debt financing declines as debt increases, while the cost increases, therefore, to maximize the overall value of the firm, firms have to focus on the trade off when choosing how much debt and equity to use for financing.

\subsection{Agency Cost Theory}

Agency costs theory expresses the conflicts between owners and managers. Owners surely expect managers to maximize their wealth through their decisions. In contrast, managers seek to increase their salaries and reward, without paying good attention to the wealth of the owners. Therefore, the conflict between the owners and managers occur when the owners' agent "managers" places their personal financial interests the owners'. Agency costs can be either:

A) The costs borne by the firm if the management uses the firm's resources for their own benefit; and

B) The cost of means that owners use to stop the managers from achieving their own interests over the owners'.

To stop or mitigate the agency problem, owners sometimes provides incentives to keep their interest in the top. This usually means paying bonuses to managers if and when the value of the firm increases. These monetary incentives are an example of agency costs. If the incentive plan works as expected, then, these agency costs will be less than the cost of allowing the agents to act in their own interests.

Denis and Milov (2002) argue that a firm's decision to fund through debt means that the firm will be restricted 
by the debt holder and this fruition a control means optionally chosen by the firms' owners. De Andres Alonso, Inturriaga, Sanz and Gonzalez (2005) agrees with this view, and proposed that this action is also a signal of a pledge to self-regulation, which reduces debt agency costs.

\subsection{Life Stage Theory}

Frielinghaus, Mostert and Firer (2005), states that the basic idea of organizational life stage theory is that firms growth through a number of life stages that begins at birth and ends in death. Bender and Ward (1993) argued that the capital structure of a firm could be influenced by its life stage, because financing needs could vary as firm's circumstances do. Bender and Ward also maintained that business risk decreases with the progress of the company's age, allowing financial risk to increase.

Hovakimiam, Opler and Titman (2001) argued that firms should utilize a higher ratio of debt to finance fixed assets, and therefore firms should have higher debt in their capital structure as they mature. Frielinghaus, Mostert and Firer (2005) Concluded to the same conclusion that mature companies have more debt in their capital structure.

\section{Methodology}

This study adopts the scientific analytical approach by using the unbalanced pooled Ordinary Least Square (OLS) cross-sectional time series panel data regression approach in order to attain the study's aims and test its hypotheses.

\subsection{Data Collection}

The data needed for the study were selected figures from the financial statements of the all listed firms on ASE for the time period of year 2000 to 2013 after excluding the financial sector and services sector, due to their own characteristics, result in 1082 firm-year observations. Needed financial information was available at the website of the Amman Stock Exchange (ASE).

\subsection{Variables}

This study consists of two main groups variables which are Leverage as independent variable and firms' performance as dependent variables.

\subsubsection{Dependent Variable (ROA)}

The return on asset (ROA) is the dependent variable in the econometric model of the study defined as the ratio of annual net income to total assets of a business during a financial year. It measures the ability of the firm to generate net income using its available assets. ROA can be computed as:

\subsubsection{Independent Variable}

$$
R O A=\frac{\text { annual net income }}{\text { total assets }}
$$

The capital structure (leverage) is the independent. Two proxies for the leverage were utilized as follows:

- $\quad$ The Long-term Debt to Capitalization Ratio (LtDC)

The Long-term Debt to capitalization Ratio computes the proportion of a firm's long-term debt compared to its total capital. LtDC can be computed as follows:

$$
L t D C=\frac{\text { long term debt }}{\text { total capital }}
$$

- $\quad$ The Total Debt to Capitalization Ratio (TDC)

A metrics of a Firm's financial leverage, defined as the ratio of the firm's debt to the total capital. Debt includes all short-term and long-term liabilities. Total capital includes the firm's debt and equity rights, which includes common stock, preferred stock, minority interest and net debt. TDC can be computed as follows:

$$
\mathrm{TDC}=\frac{\text { total debt }}{\text { total capital }}
$$

\subsubsection{Control Variable}

A number of firm level characteristics have been identified in previous empirical research that have impart on the firms value. These include sales growth, firm size and asset structure.

- $\quad$ Sales Growth (SG)

Following Zuraidah et al. (2012) the sales growth is defined as the annual growth rate of the sales as follows: 


$$
\mathrm{SG}=\frac{\text { sales }_{t} \text {-sales }_{t-1}}{\text { sales }_{t-1}}
$$

- $\quad$ Firm's Size (FS)

Following Ramadan (2013) the firm's size is measured by the natural logarithm of the firm's total assets, as follows:

$$
F S=\ln (\text { total asset) }
$$

- $\quad$ Assets Structure (AS)

Defined as the ratio of the fixed assets to the total assets, and can be computed as follows:

$$
\mathrm{AS}=\frac{\text { total fixed assets }}{\text { total assets }}
$$

\subsection{Model}

To investigate the potential impact of the leverage on the firms' value, the general equation used in our study stated that the value of the firm is a function of its leverage level and its characteristics as follow:

$$
\text { Value }=\text { (leverage, firms' characteristics) }
$$

The two econometric models to be estimate depending on the proxy of the firms' level of leverage by converting equation 7 are as follows:

$$
\begin{aligned}
R O A_{i t} & =\alpha_{0}+\beta_{1} L t D C_{i t}+\gamma_{1} S G_{i t}+\gamma_{2} F S_{i t}+\gamma_{3} A S_{i t}+\varepsilon_{i t} \\
R O A_{i t} & =\alpha_{0}+\beta_{1} T D C_{i t}+\gamma_{1} S G_{i t}+\gamma_{2} F S_{i t}+\gamma_{3} A S_{i t}+\varepsilon_{i t}
\end{aligned}
$$

Where; ROA is the return on the assets a proxy of the firm value for $\mathrm{i}^{\text {th }}$ cross-sectional company for the $\mathrm{t}^{\text {th }}$ period, as $\mathrm{i}=1,2,3, \ldots, \mathrm{n}, \mathrm{t}=1,2,3, \ldots, 14 . \alpha_{0}$ is constant. $\beta_{1}$ unknown parameters of the firms' leverage level, which take one of the two alternative measures: LtDC and TDC, to be estimated. $\gamma$ 's parameters of control variables included in the econometric models to be estimated. FS is the firm's size. SG is the sales growth. AS is the assets structure. $\varepsilon_{\text {it }}$ the error.

\section{Empirical Results}

Table 1 shows the results of the descriptive statistics analysis for all variables included in the study. It shows that the return on assets in average for the Jordanian firms in the sample of the study is 0.076 with a standard deviation of 3.54. The highest value of ROA is 0.333 and the lowest value ROA is -0.236 .

Table 1. Descriptive analysis

\begin{tabular}{ccccc}
\hline Variables & Mean & Min. & Max. & Std Dev. \\
\hline ROA & 0.076 & -0.236 & 0.333 & 3.54 \\
LtDC & 0.35 & 0.16 & 0.52 & 8.84 \\
TDC & 0.45 & 0.21 & 0.63 & 4.41 \\
FS & 16.08 & 14.09 & 18.65 & 1.12 \\
SG & 0.03 & -0.37 & 0.26 & 1.15 \\
AS & 0.67 & 0.52 & 0.92 & 0.36 \\
\hline
\end{tabular}

Note. ROA is the return on. LtDC is the long-term debt to total capitalization ratio. TDC is the total debt to capitalization ratio. FS is the firm sizes. SG is the sales growth ratio. AS is the assets structure.

Long-term debt (LtDC) which is measured by the ratio of Long-term debt to total capital has an average value of 0.35. Its standard deviation is 8.884, the maximum value of the LtDC 0.52 and the lowest value is 0.16 . The average Total debt (TDC), measured by the ratio of total debt to total capital, is 0.45 , with a standard deviation of 4.41. The value of TDC ranged between 0.21 to 0.63. For size (FS), measured by the Ln (Total Asset), has an average of 16.08. Sales growth and assets structure have an average of 0.03 and 0.67 respectively. 
Table 2. Pearson correlation matrix

\begin{tabular}{cccc}
\hline & ROA & LtDC & TDC \\
\hline ROA & 1 & & \\
LtDC & $-.231^{* *}$ & 1 & \\
& .000 & $-.788^{* *}$ & \\
TDC & $-.468^{* *}$ & .007 & 1 \\
& .009 & $.014^{*}$ & .012 \\
FS & $.132^{*}$ & .039 & .053 \\
& .041 & $-.041^{*}$ & $-.037^{*}$ \\
SG & $.828^{*}$ & .047 & .028 \\
& .023 & $.191^{*}$ & .173 \\
AS & $.001^{*}$ & .047 & .107 \\
\hline
\end{tabular}

Note. *,**. Correlation is significant at 0.05 and 0.01 level (2-tailed) respectively. The first line is the correlation coefficient; second line is the p-value. ROA is the return on. LtDC is the long-term debt to total capitalization ratio. TDC is the total debt to capitalization ratio. FS is the firm sizes. SG is the sales growth ratio. AS is the assets structure.

Table 2 shows the Pearson correlation analysis results. Table 2 shows that leverage level of the firm, expressed as LtDC and TDC, is significantly inversely correlated to the firm value expressed as ROA. The analysis shows that while the firm value ROA is significantly inversely correlated to the long term debt capitalization ratio (Corr= -0.231 , p-value $=0.000$ ), it's also significantly correlated inversely with the total debet capitalization ratio (Corr= -0.468 , p-value $=0.009)$. Results also shows that the ROA is significantly positively correlated to the firm size (FS) $($ Corr $=0.132$, p-value $=0.041)$, sales growth $(\mathrm{SG})($ Corr $=0.828$, $\mathrm{p}$-value $=0.028)$ and assets structure $(\mathrm{AS})$ (Corr $=0.001$, p-value $=0.048)$.

Table (3) presents the regression analysis results; two models were estimated model 1 related to equation 8 , where model 2 related to equation 9.

Table 3. Regression analysis results (dependent variable: ROA)

\begin{tabular}{lll}
\hline & Model 1 & Model 2 \\
\hline LtDC & $-0.307^{*}$ & - \\
& .039 & $-.271^{*}$ \\
TDC & - & .046 \\
& & $1.267^{*}$ \\
FS & $1.921^{*}$ & .0253 \\
& .0141 & $2.841^{*}$ \\
SG & $1.917^{* *}$ & .046 \\
& .007 & 23.571 \\
AS & 13.859 & .805 \\
\hline Adjusted & .719 & \\
\hline R-Square & & .627 \\
df Regression & 0.649 & 5 \\
Residual & 5 & 1076 \\
Total & 1076 & 1081 \\
N & 1081 & 1082 \\
F-value. & 1082 & 17.294 \\
p-value & .19 .924 & 0.000 \\
\hline
\end{tabular}

Note. Dependent variable: ROA a proxy of the firm value, First line regression coefficient, Second line sig. (2-tail). **, *; significant at 0.01 , 0.05 level respectively. LtDC is the long-term debt to total capitalization ratio. TDC is the total debt to capitalization ratio. FS is the firm sizes. SG is the sales growth ratio. AS is the assets structure.

Table 3 shows that after controlling for size, sales growth and assets structure, long term debt and total debt, proxies for leverage, found to be significantly affecting the firm value (ROA). LtDC, in model 1, found to be 
negatively associated with the firm value as the regression coefficient of LtDC is -0.307 with p-value $=0.039$. This result was confirmed in model 2, as table 3 indicate a negative significant association between the second leverage proxy, TDC, and firms' value with coefficient $=-0271$ and $p$-value $=0.046$. Thus, we can conclude that the long and total debt significantly have a negative impact on the firms' value. Table 3 also shows that the firm's value is positively significantly affected by the firms' size and the sales growth, but not the assets structure.

\section{Conclusion}

This study aimed to investigate the assumed impact of the leverage on the firms' value. Utilizing unbalanced pooled Ordinary Least Square (OLS) cross-sectional time series panel data regression approach to all listed companies in Amman Stock Exchange (ASE) during the period 2000-2013 after excluding the financial sector and services sector, due to their own characteristics. F-test was used to test the hypothesis that the changes in the firms' leverage level significantly explains the changes in the firms' value, and biased on the value of $p$-value's of the independent variables, the p-value of the allover model in model 1 and model 2 and the value of the explanatory power of the models, the adjusted R-square, which range from $62.7 \%$ to $64.9 \%$, we can conclude that the firms' leverage level affect the firms' value for the Jordanian listed companies included in the sample test. This result is consistent with the result of Rajan and Zingales (1995) who find negative relationship between debt and profitability.

This unexpected result can be explained by view of De Wet (2006) who states that significant amounts of value can be unlocked in moving closer to the optimal level of gearing, and Modigliani and Miller (1963), who concluded that a firms cost of equity increases as the firm increases its debt. This would support the negative impact of leverage on the firm's value.

\section{Acknowledgements}

The author is grateful to the Applied Science Private University, Amman, Jordan, for the financial support granted to this research project (Grant No. DRGS-2014-2015-54).

\section{References}

Bender, R., \& Ward, K. (1993). Corporate Financial Strategy. Oxford: Butterworth-Heinemann.

De Andries Alonso, P., Iturriaga, F. J. L., Sanz, J. A., \& Gonzalez, E. V. (2005). Determinants of bank debt in continental financial system: Evidence from Spanish companies. The Financial Review, 40, 305-333. http://dx.doi.org/10.1111/j.1540-6288.2005.00104.x

De Wet, J. H. H. (2006). Determining the optimal capital structure: A practical contemporary approach. Meditari Accountancy Research, 14(2), 1-16. http://dx.doi.org/10.1108/10222529200600009

Denis, D., \& Mihov, V. (2002). The choice among bank debt, non-bank private debt and public debt: Evidence from new corporate borrowings. Journal of financial Economics, 70, 3-28. http://dx.doi.org/10.1016/S0304-405X(03)00140-5

Ebaid, I. E. (2009). The Impact of Capital-Stucture Choice on Firm Performance: Empirical Evidence from Egypt. The Journal of Risk Finance, 10(5), 477-487. http://dx.doi.org/10.1108/15265940911001385

Ehrhardt, M. C., \& Brigham, E. F. (2003). Corporate Finance - A focused approach. Mason: Thomson.

Fama, E., \& French, K. (2002). Testing trade-off and pecking order predictions about dividends and debt. The Review of Financial Studies, 15(1), 1-33. http://dx.doi.org/10.1093/rfs/15.1.1

Firer, C., Ross, S. A., Westerfield, R. W., \& Jordan, B. D. (2004). Fundamentals of Corporate Finance (3rd ed.). Berhshire: McGraw Hill.

Frank, M. Z., \& Goyal, K. (2003). Testing pecking order of capital structure. Journal of Financial Economics, 67, 217-248. http://dx.doi.org/10.1016/S0304-405X(02)00252-0

Frielinghaus, A., Mostert, B., \& Firer, C. (2005). Capital Structure and the firm's life stage. South African Journal of Business Management, 36(4), 9-18.

Hovakimian, A., Opler, T., \& Titman, S. (2001). The debt-equity choice. Journal of Financial and Quantitative Analysis, 36(1), 1-24. http://dx.doi.org/10.2307/2676195

Kraus, \& Litzenberger, R. H. (1973). A State-Preference Model of Optimal Financial Leverage. Journal of Finance, 911-922. http://dx.doi.org/10.1111/j.1540-6261.1973.tb01415.x

Lasher, W. R. (2003). Practical Financial Management (3rd ed.). Mason Thomson.

Modigliani, F., \& Miller, M. H. (1963). Corporate Income Taxes and The Cost of Capital: A Correction. 
American Economic Review, 53, 433-443.

Modiglinai, F., \& Miller, M. H. (1958). The Cost of Capital, Corporate Finance and the Theory of Investment. American Economics Review, 48, 261-297.

Myers, S. C., \& Shyam-Sunder. (1999). Testing Tradeoff Against Pecking Order Models of Capital Structure. Journal of financial Economies, 51, 219-244.

Pandey, I. M. (2004). Financial Management (9th ed., pp. 289-350). Indian Institute of Management, Ahmedabad. Vikas Publishing. House P.VT. LTD.

Rajan, R. G., \& Zingales, L. (1995). What do we know about capital structure? Some evidence from international data. The Journal of Finance, 50(5), 1421-1460. http://dx.doi.org/10.1111/j.1540-6261.1995.tb05184.x

Ramadan, I. Z. (2013). Debt-Performance Relation. Evidence from Jordan. International Journal of Academic Research in Accounting, Finance and Management Sciences, 3(1), 323-331.

Sharma, A. K. (2006). Financial Leverage and Firm's Value: A Study of Capital Structure of Selected Manufacturing Sector Firms in India. The Business Review, 6(2), 70-76.

Tian, G. G., \& Zeitun, R. (2007). Capital structure and corporate performance: Evidence from Jordan. Australian Accounting Bussiness and Finance Journal, 1(4).

Ward, M., \& Price, A. (2006). Turning Vision into Value. Pretoria: Van Schaik Publishers.

Zuraidah, A., Norhasniza, M. H. A., \& Shashazrina, R. (2012). Capital Structure Effect on Firms Performance: Focusing on Consumers and Industrials Sectors on Malaysian Firms. International Review of Business Research Papers, 8(5), 137-155.

\section{Copyrights}

Copyright for this article is retained by the author(s), with first publication rights granted to the journal.

This is an open-access article distributed under the terms and conditions of the Creative Commons Attribution license (http://creativecommons.org/licenses/by/3.0/). 